\title{
Efficacy of EFL Teachers' Assessment Literacy and Professional Identity in Boosting Learners' Autonomy
}

\author{
Hooshang Yazdani \\ Department of English Language and Literature, Arak University, Arak, Iran \\ Parviz Ghasedi \\ Department of English Language and Literature, Arak University, Arak, Iran
}

\begin{abstract}
This study was set out to investigate the effects of EFL teachers' assessment literacy and professional identity on learners' autonomy. Meanwhile, the relationship between teachers' assessment literacy and professional identity was investigated. Moreover, educators' perspectives on learner autonomy were studied. To this end, 40 EFL teachers participated in the study through completing assessment literacy scale developed by Mertler (2003) and teacher professional identity questionnaire designed by Beijaard et al. (2000). Besides, 20 EFL teachers were interviewed. Likewise, 110 upper-intermediate EFL learners answered Zhang and Li's (2004) learner autonomy questionnaire. A mixed method design was used to answer the research questions. The findings revealed that teachers' assessment literacy was linked to their professional identity. Moreover, assessment literacy and professional identity had fruitful effects on learner autonomy. The findings made it certain that teachers believed in learners' abilities however they didn't know how to cultivate autonomous learners.
\end{abstract}

Index Terms - assessment literacy, autonomy, professional identity

\section{INTRODUCTION}

The vital roles of teachers in educational context are undeniable. Teachers are considered as the main sources for selecting materials, arranging the classrooms, providing learning opportunities, and assessing learners' advancement. Therefore, teacher's professional identity and assessment literacy are considered as crucial components in determining the effectiveness of any educational context. On the other hand, equipping learners with skills to be autonomous received the attention of lots of teachers and researchers nowadays. Accordingly, this study tries to investigate the effects of teacher's professional identity and assessment literacy on learners' autonomy.

Professional identity relates to teacher self-conception based on his/her experiences, perspectives, and believes (Ibarra, 1999). Timoštšuk and Ugaste (2010, p. 1564) refer to teacher professional identity as teacher understanding of "teaching related situations and relationships that manifest themselves in practical professional activities". Bullough (1997) considers teacher identity as the essence of teacher decisions. It roots in sociocultural factors (Mofrad, 2016) and influences teacher manner and behavior (Abednia, 2012). Caihong (2011) notes that teachers' professional identities determine their interpretations of learners' behavior and improvements; it also effects teachers' teaching methods. Ivanovaa and Skara-Mincfne (2016) mention that professional identity is linked to effective teaching. Therefore, effective teachers have positive professional identities.

van Huizen et al. (2005) argue that one of the main aims of teacher training courses is boosting educators' professional identities. Research indicates that teacher professional identity is linked to teaching quality (Veisson \& Kabaday, 2018) and teacher pedagogical content knowledge (Atai \& Khazaee, 2014). Moreover, teachers with high level of professional identity have better relationships with learners (Rockoff, 2004) and are more effective in teaching, understanding learners' needs, solving problems, and transferring knowledge (Levine, 2006).

Assessment and learning opportunity are considered as two main concepts in language teaching. Creating appropriate contexts and providing accessible input seems not to be enough for language acquisition. Assessment determines learners' strengths and weaknesses. It helps teachers to design, adopt, or change teaching methods. Likewise, assessment determines the quality and effectiveness of teaching (Stiggins, 1999). Therefore, teacher knowledge of assessment has direct effects on learners' outcomes (Bennett, 2011). Messick (1989) mentioned that teachers should have accurate and acceptable knowledge of the effects, results, and consequences of assessment.

In the same line, Stiggins (1991) coined the concept of assessment literacy and defined it as teacher comprehension of appropriate assessment. Ainsworth and Viegut (2006, p.53) described it as "the ability to understand the different purposes and types of assessment in order to select the most appropriate type of assessment to meet a specific purpose" (p. 53). More specifically in applied linguistics, the notion of language assessment literacy was defined as "the ability to design, develop and critically evaluate tests and other assessment procedures, as well as the ability to monitor, evaluate, 
grade and score assessments on the basis of theoretical knowledge" (Vogt \& Tsagari, 2014, p. 377). Language Assessment Literacy (LAL) is vital competence for stakeholders involved in language teaching and assessment (Taylor, 2009; Yastıbaş \& Takkaç, 2018). Scarino (2013) believed that developing LAL is necessary for a teacher. LAL helps educators to evaluate their attitudes, believes, actions, and understandings (Scarino, 2013). On the other hand, the low level of LAL leads to an invalid evaluation of a learner (Suah, 2012).

The third variable of this study is learner autonomy. Autonomy refers to learners' "ability to take charge of one's own learning" (Holec, 1981, p. 3). Nunan (2003) viewed autonomy as students' capacity to monitor their acquisitions. Benson (2001) argued that autonomy has three main levels. These levels include monitoring learning, learning contents, and cognitive process (Benson, 2001). Little (2009) mentioned that autonomous learners do their works independently. Holec (1981) asserts that being autonomous enable learners to set goals, select contents, choose appropriate methods, control their learning, and assess their progress. Ghasedi et al. (2018) note that autonomous learners are more willing to participate in classroom interactions and negotiations. Zarei and Gahremani (2010) added that learners with the higher level of autonomy are more active and effective in language acquisition.

The review of literature indicated that autonomy is linked to motivation (Hua, 2009; Li \& Yu, 2008) self-efficacy (Li \& Yu, 2008; Wu \& Zhang, 2009) effective learning (Vickers \& Enn, 2006), critical thinking (Fahim \& Haghighi, 2014), language proficiency (Qi, 2011), and speaking fluency, accuracy, and complexity (Ghasedi et al., 2018) The efficacy of teachers' professional identity and assessment literacy is well documented. Likewise, a conclusive review of previous studies indicates that learner autonomy is a vital variable in language acquisition. Some studies were conducted in this regard; however, no study investigated the links between teacher professional identity and assessment literacy. Moreover, no study investigated the effects of language assessment literacy and professional identity on learner autonomy. Accordingly, this study was set out to fill the gaps and find plausible answers to the following questions:

1. Do teachers' assessment literacy and professional identity affect learners' autonomy?

2. Is there any links between teachers' assessment literacy and their professional identity?

3. What are teachers' perspectives about learners' autonomy?

\section{LITERATURE REVIEW}

\section{A. Professional Identity}

Professionalism has different meanings for different individuals (Fox, 1992). It is considered as a quality of any profession (Hoyle, 1980). Professional identity refers to the continuous procedure of understanding and re-translation of encounters (Kerby, 1991). In educational contexts, it is defined as the characteristics and behaviors of an expert educator (Hoyle, 1980). Lasky (2005) refers to teacher professional identity as the way educators characterize their jobs. Ashforth and Tomiuk (2000) contend that professional identity includes individual, expert, and situational factors. They added that in different contexts one of these factors became prevailing. Kompf et al. (1996) mentioned that teachers' professional identities determine their attitudes, convictions, actions, and reactions.

Considering professionalism as one of the main characteristics of a professional teacher, McBer (2000) noted that responsibility, certainty, reliability, and regard are the main dimensions of teacher professional identity. Hoyle and John (1995) considered responsibility, autonomy, and knowledge as three main components of professional identity. David (2000) believed that hypothetical and practical ability, autonomy, ethicality, open assistance, and discipline were the main subcomponents of professional identity.

Asserting that the identity of a teacher develops during teaching; Beauchamp and Thomas (2009) add that teachers' professional identities enable them to shape their value system about how to comprehend their roles or how to be in school or society. Moore and Hofman (1988) noted that the higher the teachers' professional identity the lower their job dissatisfaction and work stress. Gaziel (1995) showed that professional identity was negatively correlated with teacher burnout. İlgan et al. (2015) put forth that teachers with high professional identity spent more time on teaching tasks in order to increase the quality of teaching.

The results of Veisson and Kabaday (2018) indicated that the lower the teachers' professional identity, the lower their teaching quality. Aghaalikhani and Maftoon (2018) studied the effects of EFL teaching programs on teachers' professional identities. They collected data from 150 Iranian EFL teachers. Their findings showed that teacher education programs only improved two dimensions of professionalism (professional development and reflection) and had no significant effects on responsibility and ethics. They added that context and politics are two main factors that affect teacher professional identity.

\section{B. Language Assessment Literacy}

Assessment has different functions in various educational contexts. Fulcher (2010) summarized the main functions of an assessment as providing information to make decisions, gatekeeping, diagnose learner level, motivate student, and impose specific political and social norms. Likewise, assessment has lots of advantages such as providing data to improve teaching styles, control learner learning, make students aware of their competence, and improve learners' selfesteem (Yamtima \& Wongwanich, 2014). Moreover, the direct link between teaching and assessment implies that assessment improves teaching (Malone, 2013). Consequently, assessment literacy or more specifically LAL could be considered as one of the main requirements of an effective teacher. 
Assessment literacy refers to teacher sound understanding of the principles of evaluation, methods of assessment, assessment criteria, and assessment tools and strategies (Mertler, 2003; Popham, 2004; Volante \& Fazio, 2007). Arguing that assessment literacy involves theoretical and practical knowledge, Taylor (2009, p. 27) added that such knowledge should be contextualized "within a sound understanding of the role and function of assessment within education and society". The highly cited definition of LAL, proposed by Fulcher (2012, p. 125) is as:

- "Knowledge, skills and abilities required designing, developing, maintaining or evaluating" different kinds of language tests.

- Awareness of assessment strategies and familiarity with underling standards and ideas that guide and support evaluation

- The capacity to implement such knowledge and skills "within wider historical, social, political and philosophical frameworks"

Stiggins (1999) numbered the main criteria for a teacher to be assessment literate as starting with a specific purpose of assessment in mind, determining the level of requirement, selecting suitable methods of assessment based on the purpose and level of requirement, developing accurate test rubric, avoiding subjectivity in scoring, and giving appropriate feedback based on learners' scores. These criteria were summarized by National Council on Measurement in Education (NCME), National Education Association (NEA), and American Federation of Teachers (AFT) in 1990. These criteria include being skillful in choosing suitable methods for assessment, designing or implementing accurate tools for assessment, taking the exam, scoring the answer sheets, and reporting the results, making differentiation between learners based on their scores, transferring the results of assessment to learners, learners' parents, and other stakeholders, and being aware of the differences between ethical and unethical assessment and being unwilling to use unethical ones. Such criteria help teachers evaluate learners fairly (Lian \& Yew, 2016). Fulcher (2010) believed that the teachers who have high level of LAL are able to distinguish notions like assessment for learning from assessment of learning. Likewise, they are familiar with different kinds of assessment such as formative, summative, self/peer assessment, and dynamic assessment (Fulcher, 2010). Accordingly, they can choose the best one based on their needs and contexts.

Tsagari and Vogt (2017) investigated European EFL teachers LAL. Their findings indicated that teachers felt that they had low level of LAL. The participants in the study noted that their LAL was not enough for assessment activities. Tsagari and Vogt (2017) mentioned that teacher training courses didn't prepare teachers to use assessment tools, strategies, and routines. In a similar study Volante and Fazio (2007) concluded that Canadian college teachers had low level of assessment literacy. They added that those teachers need more training on classroom assessment. The findings of Shim (2009) showed that teachers were assessment literate; however, they didn't implement lots of assessment principles into practice. Xu and Brown (2017) reported that there wasn't significant difference between male and female teachers concerning assessment literacy.

\section{Learners' Autonomy}

Autonomy has different interpretations in different cultures (Kumaravadivelu, 2012). It was regarded as learners' responsibility for their improvement (Brindley, 1990). Being autonomous refers to being able to make decision for one's own advancement. Taking the needs lacks, wants, and goals into account, autonomous learners are able to direct and manage their studying. Having the clear understanding of their purposes, duties, and expectations autonomous learners review their progress and assess their changes (Holec, 1981).

Kumaravadivelu (2012) divided the autonomy into two kinds of academic and liberatory. He viewed academic autonomy as a narrowed view which aims to develop learners' academic abilities. Kumaravadivelu (2012) added that this kind of autonomy boosts learner's understandings of how to learn. On the other hand, the liberatory autonomy considered the academic autonomy as a mean to learning to liberate. Liberatory autonomy enables students to "recognize sociopolitical impediments placed on their paths to progress and provide them with the intellectual tools necessary to overcome them" (Kumaravadivelu, 2012, p. 47). This broad view of autonomy develops learners' critical thinking abilities (Kumaravadivelu, 2012).

Benson (2001) maintained that training learners are necessary for developing their autonomy. Balçıanli (2010) proved that teachers have the high tendency to develop learners' autonomy. Chen (2011) showed that the autonomy of teachers directly affect the autonomy of students. Birchley (2003) viewed teachers in autonomous contexts as assistors, models, suppliers, advisors, and instigators. Üstünlüoğlu (2009) compared teachers and learners' perception of autonomous classrooms. The findings indicated that students had the capacity to monitor their learning; however they didn't have the willingness to do so. On the other side, teachers perceived learners incapable of taking charge of their own learning.

Dafei (2007) examined the relationship between learner autonomy and language proficiency. Findings highlighted the differences between learners with different levels of autonomy. The findings of Sakai and Takagi (2009) and Yasmin and Sohail (2017) proved such results and showed a positive correlation between learners' autonomy and language proficiency. Zarei and Gahremani (2010) showed the significance of learners' autonomy in developing their reading comprehension. Zhalehgooyan and Alavi (2014) reported the efficacy of autonomy in developing learners' listening comprehension. 
A conclusive review of the previous studies highlights the significance of teachers' professional identity and assessment literacy. The benefits of autonomy in language acquisition and advancement were also accentuated. Some studies have been conducted in this regard; however, no studies examined the links between teachers' professional identity and assessment literacy. Moreover, no study addressed the effects of teachers' professional identity and assessment literacy on learners' autonomy. Therefore, this study was set out to fill the gaps and provide fruitful theoretical and pedagogical implications in this regard.

\section{METHOD}

\section{A. Participants}

Forty EFL teachers (17 males and 23 females) participated in this study. Their age ranged from 28-45 and all of them were Persian native speakers. They were selected from three cities (Qorveh, Dehgolan, and Sannandaj) of Kordestan province, Iran. They had different years of teaching experiences, ranged from 5 years to 15 years. It should be noted that they taught EFL in different private institutes.

Likewise, 110 upper-intermediate EFL learners (47 males and 63 females) answered learner autonomy questionnaire. They were Persian and Kurdish native speakers who had no opportunities to talk to native speakers. Their age ranged from 16-22.

\section{B. Instruments}

\section{Assessment Literacy Scale}

The first instrument that was used in this study was classroom assessment literacy inventory developed by Mertler (2003). It was adopted from Teacher Assessment Literacy Questionnaire developed by Plake et al. (1993). Classroom assessment literacy inventory involves two parts. The first part includes 35 items (4 choices for each item) about seven standards concerning teacher assessment knowledge. These standards include teacher skill in selecting appropriate and accurate assessment methods (items 1,2,3,4, and 5), designing and developing methods for assessment (items 6,7,8,9, and 10), administrating the test, scoring it, and making meaning of scores (items 11, 12, 13, 14, and 15), taking appropriate action based on test result (items 16, 17, 18, 19, and 20), gradation and categorization of learners (items $21,22,23,24$, and 25), reporting the test results (items 26,27,28,29, and 30), and detecting biased, illegal, and inaccurate items (items 31, 32, 33, 34, and 35). The second part of classroom assessment literacy inventory asks questions about teachers' backgrounds such as gender, educational level, and general knowledge concerning teaching and assessment. The reliability of the instrument conducting Cronbach's alpha was 97 (Mertler, 2003).

\section{Professional Identity Questionnaire}

Teacher professional identity questionnaire developed by Beijaard et al. (2000) was used to measure teacher professional identity. The scale consists of four sections. The first section includes questions about teacher's years of experience, age, subject matter taught, and gender. The second section asks questions about subject matter field (item1, 2,3 , and 4). The third section has questions about teachers' understanding of professional teaching (items 5,6,7,8,9, and 10). The fourth section includes items about supporting learners socially, mentally, and emotionally (items $11,12,13$, and 14). The participants were asked to what extent they were agreed with each item on four-point Likert scale. The reliability of the inventory running Cronbach's alpha was .91.

\section{Learner Autonomy Scale}

The third instrument that was used in the current study was learner autonomy scale designed by Zhang and $\mathrm{Li}$ (2004). The scale has two parts. The first part involves 11 items with five options, $1=$ never, $2=$ rarely, $3=$ sometimes, $4=$ often, and $5=$ always. The second part includes 10 items in multiple-choice format. The choices ranged from A to $\mathrm{E}$ which $\mathrm{A}$ is equal to 1 point and $\mathrm{E}$ is equal to 5 points. The reliability and validity of this scale was established (Dafei, 2007).

Semi-structured interview

A semi- structured interview was conducted to investigate teachers' perspectives about learners' autonomy. The interview includes five questions with follow up questions (Appendix A). The interview questions focused on teachers' perspective about learner autonomy. Moreover, some questions were asked about the teacher training programs, conferences, and workshops. It's worth noting that the validity of the interview was confirmed by two experts who had P.h.D in applied linguistics.

\section{Data Collection Procedures}

The researcher obtained the permission from heads of institutes and teachers before conducting the study. Moreover, the participants were asked if they wanted to participate in the study. Teachers and learners were given necessary instruction concerning answering the scales. Then, the classroom assessment literacy inventory was distributed among teachers. They were given enough time to answer the questions. After ten minutes brake, the professional identity scale was distributed. Teachers were given necessary information concerning how to answer the scale. The questionnaires were collected after completing. Learner autonomy scale was administered among language learners to measures their autonomy. The researcher guides learners and translate the words or expressions that caused difficulty for them.

It should be noted that the two different meetings were held in each city (Qorveh, Dehgolan, and Sanandaj) for collecting data; one meeting for teachers and the other one for learners. 
The interview was administered by the researcher. Teachers were selected based on availability and willingness to participate in the interview. The interviews were conducted in the institutes that the teachers worked. The researcher went to the institute one by one and invited the teachers into a room. The time of each interview lasted 20 minutes. The researcher transcribed the teachers' answers.

\section{RESULTS AND DISCUSSION}

The collected data were codified and entered into SPSS version 21. To answer the first research question Pearson Product Moment Correlation was used. The results of descriptive statistics are presented in Table 1 and the results of correlation are shown in Table 2.

TABLE 1.

\begin{tabular}{|c|c|c|c|}
\hline & $\mathrm{N}$ & $\mathrm{M}$ & Std. Deviation \\
\hline assessment literacy & 40 & .792 & .227 \\
\hline professional identity & 40 & 3.246 & .115 \\
\hline
\end{tabular}

Table 1 shows that the mean and standard deviation for assessment literacy and professional identity are $\mathrm{M}=.792$, Std. $=.227$ and $\mathrm{M}=3.246$, Std. $=.115$, respectively.

TABLE 2

\begin{tabular}{|c|c|c|}
\hline \multicolumn{3}{|c|}{ Professional identity } \\
\hline & $\mathrm{R}$ & $.427^{* *}$ \\
\hline \multirow[t]{2}{*}{ Assessment literacy } & Sig. (2-tailed) & .006 \\
\hline & $\mathrm{N}$ & 40 \\
\hline
\end{tabular}

As the data in Table 2 reveals, there is a significant positive correlation between teachers' assessment literacy and their professional identity $(r=.427, \mathrm{p}=006)$. Accordingly, it could be claimed that the higher the teachers' assessment literacy, the higher their professional identity.

Results of the first question revealed that there was a positive link between teachers' assessment literacy and their professional identity. Such findings are consistent with the results of Jumardin et al. (2014). They believed that professional identity enables teachers to evaluate and guide learners better. Similarly, Connelly and Clandinin (1999) noted that teachers' identities affect the way of institutional evaluation and changes. On the other hand, teachers' identity is considered to be dynamic which is affected by many factors (Beijaard et al., 2000; Bressler \& Rotter, 2017; Kostogriz \& Peeler, 2007; Wang \& Du, 2014). Beauchamp and Thomas (2009) asserted that teachers' professional identities are formed by their encounters. Kostogriz and Peeler (2007) showed that teaching and interactions among teachers and learners have significant role in developing learners' professional identity. Accordingly, assessing learners and giving feedbacks to interlocutors could be considered as one of the main factors in developing teachers' professional identity.

Moreover, Ivanovaa and Skara-MincIne (2016) added that the contextual setting provides the ground for developing teachers' professional identities. Hence, the sociocultural setting of teaching and evaluation a combined by factors that were mentioned for being assessment literate teachers and teachers trying to achieve such factors boost teacher professional identity. Factors like having the accurate understanding of the subject matter field, principles and methods of assessment, reporting the assessment results, and consequences of assessment improve teachers' professional identity. In sum, it seems that there is a direct link between assessment literacy and professional identity which implies that assessment literacy improves professional identity and professional identity improves assessment literacy.

The second question investigates the effects of teachers' assessment literacy and professional identity on learners' autonomy. The results of statistical analysis are depicted in Table 3 and Table 4.

TABLE 3

\begin{tabular}{llll} 
DESCRIPTIVE STATISTICS FOR TEACHERS' & ASSESSMENT LITERACY/PROFESSIONAL IDENTITY AND LEARNERS' AUTONOMY \\
\hline Learners' autonomy & $\mathrm{N}$ & $\mathrm{M}$ & Std. Deviation \\
Assessment literacy & 110 & 2.919 & .295 \\
Professional identity & 40 & .792 & .227 \\
\hline
\end{tabular}

The mean and standards deviation of teachers' assessment literacy and professional identity were discussed in the previous question. The mean and standards deviation of learners are 2.919 and .295 respectively. 
TABLE 4.

CORRELATION COEFFICIENT OF ASSESSMENT LITERACY, PROFESSIONAL IDENTITY, AND AUTONOMY

\begin{tabular}{|c|c|c|c|}
\hline \multirow{3}{*}{ Learners' autonomy } & & Assessment literacy & Professional identity \\
\hline & $\mathrm{R}$ & $.415^{* *}$ & $.429^{* *}$ \\
\hline & Sig. (2-tailed) & .008 & .006 \\
\hline
\end{tabular}

Table 4 revealed that there are positive correlation between language learners' autonomy and EFL teachers assessment literacy $(\mathrm{R}=.415, \mathrm{p}=008)$ and professional identity $(\mathrm{R}=429, \mathrm{p}=.006)$. Therefore, it could be concluded that teachers' assessment literacy and professional identity have direct effect on learners' autonomy.

The results of second research question revealed that learners' autonomy is influenced by teacher identity and assessment literacy. Therefore, such variables could be considered as two main factors in developing language learners' autonomy. These findings are supported by the results of Morgan (2004) and Varghese et al. (2005). Varghese et al. (2005) showed that the style of teaching influences learner participation in class activities. It should be noted that active participation in classroom activities is considered as one of the main characteristics of autonomous learners (Kumaravadivelu, 2012). Besides, Chen (2011) reported that teacher characteristics influence learners' autonomy. Moreover, Zarei and Gahremani (2010) considered teachers as facilitators of learners' autonomy. Gao et al. (2013) asserted that teachers' evaluation and teaching affect students' characteristics.

In light of the results of the current study it could be argued that teachers' personality, competence, and skillfulness affect learners' autonomy. It seems that autonomous teachers inbreed autonomous learners. Therefore, to have independent and active learners there should be proficient and literate teachers.

The last question investigates teachers' perspectives about learners' autonomy. The results of interviews revealed that the main characteristics of autonomous learners are being self-confident, curious, creative, flexible, independent, risk taker, critical thinker, good guesser, tolerant, motivated, and goal setter. Moreover, they believed autonomous learners prefer student-centered classrooms. Most of the teachers' confirmed that their students were motivated language learners, but they didn't believe in themselves. They argued that the language learners relied too much on textbooks and teachers. The learners didn't have necessary confidence and skills to take charge of their learning. They argued that sometimes they give learners the opportunities to select the topics for discussion. However, learners gained no opportunity to select content. The main reason was student incapability to do so.

Concerning learners' responsibility teachers believed that learners should take control of their learning. Learner involvement in learning and advancement boosts their efficacy and helps them to achieve their goals. Most of the teachers believed that teacher training courses didn't pay enough attention to learner autonomy. They mentioned that during their training courses they received instructions based on predetermined books by Ministry of Education. They added that they didn't receive appropriate and accurate instructions on how to develop learner autonomy.

The findings of the third research question made it clear that most of the participants were aware of the significance of learners' autonomy. Likewise, the teachers believed in learners' capabilities, however, learners didn't believe in themselves. Besides, most of the learners didn't gain the opportunity to select the topic, content, or method. Moreover, the results showed that most of the teacher inadequacy in developing learner autonomy was related to teacher training programs. The findings are supported by the results of Aghaalikhani and Maftoon (2018). They mentioned that teacher training courses in Iran didn't provide educators necessary information about new concepts and technologies. Likewise, Ghaemi and Abdullahi (2016) noted that teachers are supposed to do some responsibilities and they have few freedoms in selecting contents and materials. Similarly Tsagari and Vogt (2017) noted that European teachers aren't only competent in new concepts but also they aren't provided with enough information in this regard. Moreover, the findings of Ivanovaa and Skara-MincIne (2016) made it clear that pre-service teachers need more contextualized guidance.

Concerning learner autonomy, the results of this study are in line with the findings of Üstünlüoğlu (2009) and Balçıkanlı (2010). Üstünlüoğlu (2009) showed that students had the capability to take charge of their improvement but they weren't tended to do so. On the other hand, Balçıkanlı (2010) asserted that teacher belief in learner skills to control their own learning. Learners' unwillingness to take charge of their own learning seems to be rooted in their backgrounds. To the best of researcher knowledge, learners are consumers of teachers' knowledge in Iran. Students have no role in selecting the books, contents, or materials. Assessments are mostly formative or summative in schools. We don't observe self-assessment, peer assessment, or dynamic assessment. Such problems should be solved by equipping teachers with needed skills and knowledge. Accordingly, teacher education programs should be fruitful.

\section{CONCLUSION}

Considering language assessment literacy, professional identity, and autonomy as vital criteria in learning and assessment, this study tried to fill the gaps in the literature through investigating the effects of EFL teachers' language assessment literacy and professional identity on learner autonomy. Moreover, the relations between teachers' professional identity and assessment literacy were examined. While many studies are required to be conducted to examine the correlation between teachers' professional identity and language assessment literacy and the effects of such variables on learners' autonomy; the results extracted from the statistical analysis of the current study made it certain that there was a positive correlation between LAL and professional identity. Likewise, findings indicated that teachers' 
LAL and professional identity had valuable effects on learners' autonomy. Finally, it was shown that teachers admitted learner autonomy however they weren't competent enough to nurture autonomous learners.

Teacher professional growth involves developing competence in the field, teaching, understanding learners, and supporting them. On the other hand, to be literate in assessment, language teachers should be competent in selecting and designing assessment methods, testing, scoring, and comparing learners, and presenting the results (Beijaard et al., 2000). Consequently, it puts many demands on teacher training programs. One of the main aims of teacher education programs can be the development of teachers' LAL and professional identity. However, teacher training courses in Iran haven't received serious attention in Iran (Aghaalikhani \& Maftoon, 2018). Ghaemi and Abdullahi (2016) asserted that language teachers in Iran are supposed to teach specific books in specific ways. This may be due to the lack of awareness of the significance of teachers' LAL and identity. Accordingly, based on the results of this study and the fact that pre-service teacher education has fruitful effects on teacher proficiency and literacy; it is recommended to provide the necessary guidance and support to plan and nourish LAL and professional identity.

\section{APPENDIX}

1. What makes an autonomous language learner?

2. How do you describe your students? Why?

3. Do you give your student any opportunity to select the topic, content, or material? Why?

4. How much is an EFL learner responsible for his/her learning? Why?

5. How do you evaluate teacher training programs, workshop, and conferences concerning learners' autonomy?

\section{REFERENCES}

[1] Abednia, A. (2012). Teachers' professional identity: Contributions of a critical EFL teacher education course in Iran. Teaching and Teacher Education, 28(25), 706-717.

[2] Aghaalikhani, H., \& Maftoon, P. (2018). English Teacher Education Programs and Professionalism: The case of Iranian Novice/Experienced Teachers. Research in English Language Pedagogy, 6(1), 78-94.

[3] Ainsworth, L., \& Viegut, D. (2006). Common formative assessments: How to connect standards-based instruction and assessment. Thousand Oaks, CA: Corwin Press.

[4] Ashforth, B. E., \& Tomiuk, M. A. (2000). Emotional labour and authenticity: Views from service agents. In S. Fineman (Ed.), Emotion in organizations (2nd ed., pp. 184- 203). London: Sage.

[5] Atai, M. R., \& Khazaee, M. (2014). Exploring Iranian EAP Teachers' Pedagogical Content Knowledge and Their Professional Identity. Issues in Language Teaching, 3(1), 35-51.

[6] Balcikanli, C. (2010). Learner autonomy in language learning: Student teachers' beliefs. Australian Journal of Teacher Education, 35(1), 90-103.

[7] Beauchamp, C., \& Thomas, L. (2009). Understanding teacher identity: an overview of issues in the literature and implications for teacher education. Cambridge Journal of Education, 39(2), 175-189.

[8] Beijaard, D., Verloop, N., \& Vermunt, J. D. (2000). Teachers' perceptions of professional identity: An exploratory study from a personal knowledge perspective. Teaching and teacher education, 16(7), 749-764.

[9] Bennett, R. (2011). Formative assessment: A critical review. Assessment in Education: Principles, Policy \& Practice, 18, 525.http://dx.doi.org/10.1080/0969594X.2010.513678.

[10] Benson, P. (2001). Autonomy in language learning. Harlow: Longman.

[11] Birchley, S. (2003). Creating Learner Autonomy: Self-Access \& an English Lounge, Japan. Bulletin of Toyo Gakuen University, $15,31-44$.

[12] Bressler, C., \& Rotter, C. (2017). The Relevance of a Migration Background to the Professional Identity of Teachers. International Journal of Higher Education, 6(1), 239-250.

[13] Brindley, G. (1990). The role of needs analysis in adult ESL programme design. In R. K. Johnson (Ed.) The second language curriculum (pp. 63-78). Cambridge: Cambridge University Press.

[14] Bullough, R. V. (1997). Becoming a teacher: Self and the social location of teacher education. In B. Biddle, T.Good, \& I. Goodson (Eds), International handbook of teachers and teaching (pp. 79-134). Springer.

[15] Caihong, H. A. O. (2011). Changes and characteristics of EFL teachers' professional identity: The cases of nine university teachers. Chinese Journal of Applied Linguistics, 34(1), 3-21.

[16] Chen, V. (2011). Authenticity and identity in the portable homeland. In T. K. Nakayama \& R. T. Halualani (Eds.), The handbook of critical intercultural communication (pp. 483-494). Malden, MA: Wiley.

[17] Connelly, F. M., \& Clandinin, D. J. (1999). Shaping a professional identity: Stories of education practice. London, ON: Althouse Press.

[18] Dafei, D. (2007). An exploration of the relationship between learner autonomy and English proficiency. Asian EFL Journal, 24(4), 24-34.

[19] David, C. (2000). Professionalism and ethics in teaching. London: Taylor \& Francis Books Ltd.

[20] Fahim, M., \& Haghighi, M. (2014). The relationship between critical thinking ability of Iranian EFL learners and their academic self-regulation. International Journal of Language Learning and Applied Linguistics World, 5(3), 390-400.

[21] Fox, C. J. (1992). What do we mean when we say" professionalism?": a language usage analysis for public administration. The American Review of Public Administration, 22(1), 1-17.

[22] Fulcher, G. (2010). The reification of the Common European Framework of Reference (CEFR) and effect-driven testing. In A. Psyaltou-Joycey \& M. Matthaioudakis (Eds.), Advances in Research on Language Acquisition and Teaching (pp. 15-26). GALA. 
[23] Fulcher, G. (2012). Assessment literacy for the language classroom. Language Assessment Quarterly, 9(2), 113-132.

[24] Gao, X., Liao, Y., \& Li, Y. (2013). Empirical studies on foreign language learning and teaching in China (2008-2011): A review of selected research. Language Teaching, 47(01), 56-79. https://doi.org/10.1017/s0261444813000414.

[25] Gaziel, H. H. (1995). Sabbatical leave, job burnout and turnover intentions among teachers. International Journal of Lifelong Education, 14(4), 331-338.

[26] Ghaemi, H., \& Abdullahi, H. (2016). EFL Teacher's Affective Constructs and Their Sense of Responsibility. Research in English Language Pedagogy, 4(1), 64-72.

[27] Ghasedi, P., Mashhady, H., \& Okati, F. (2017). The effects of homogeneous and heterogeneous pushed output instructions on speaking complexity, ENGLISH REVIEW: Journal of English Education, 6(1), 11-20.

[28] Ghasedi, P., Okati, F., Mashhady, H., \& Fallah, N. (2018). The effects of symmetrical and asymmetrical scaffolding on speaking complexity, accuracy, and fluency. Indonesian EFL Journal, 4(1), 1-10.

[29] Holec, H. (1981). Autonomy and foreign language learning. Oxford: Pergamon.

[30] Hoyle, E. (1980). Professionalization and deprofessionalization in education. In E. Hoyle \& J. E. Meggary (Eds.), The professional development of teachers (pp. 42-57). London: Kogan Page.

[31] Hoyle, E., \& John, P.D. (1995). Professionality, Professionalism and control in teaching, London Educational Review, 3(2), pp. 13-19.

[32] Hua, W. (2009). Shilun waiyu xuexi dongji yu xuexizhe zizhu. [Learner autonomy and learning motivation of foreign language]. Foreign Languages Research, 1, 57-62. https://doi.org/10.13978/j.cnki.wyyj.2009.01.024.

[33] Ibarra, H. (1999). 'Provisional Selves: Experimenting with Image and Identity in Professional Adaptation', Administrative Science Quarterly, 44, 4, 764-91.

[34] İlgan, A., Aslanargün, E., \& Shaukat, S. (2015). Öğretmenlik mesleği profesyonellik ölçeği geçerlik ve güvenirlik çalışması \{Developing teacher professionalism scale: Validation and reliability study\}. Ĕgitimde Kuram ve Uygulama, 11(4), $1454-1474$.

[35] Ivanova, I., \& Skara-Minctne, R. (2016). Development of Professional Identity During Teacher's Practice, Procedia - Social and Behavioral Sciences 232, 529-536.

[36] Jumardin, J., Bahri, S., Gani, H., \& Jasruddin, J. (2014). Analysis Of The Pedagogic Competence And Professionalism Of Lecturers In Seamanshıp Polytechnıc Makassar Based On The Sailing Period. International Journal Of Academic Research, 6(4), 176-181.

[37] Kerby, A. (1991). Narrative and the self. Bloomington, IN: Indiana University Press

[38] Kompf, B., Dworet \& Boak. (1996). Changing research and practice: Teachers' professionalism, identities and knowledge. Londra, Falmer Press.

[39] Kostogriz, A., \& Peeler, E. (2007). Professional identity and pedagogical space: Negotiating difference in teacher workplaces. Teaching education, 18(2), 107-122.

[40] Kumaravadivelu, B. (2012). Language teacher education for a global society: A modular model for knowing, analyzing, recognizing, doing, and seeing. London: Rutledge.

[41] Lasky, S. (2005). A sociocultural approach to understanding teacher identity, agency and professional vulnerability in a context of secondary school reform. Teaching and teacher education, 21(8), 899-916.

[42] Levine, A. (2006). Educating school teachers. New York: The Education Schools Project. (2020, March 19) www.edschools.org/teachers_report.htm.

[43] Li, K., \& Yu, L. (2008). Daxuesheng yingyu xuexi dongji, ziwo xiaonenggan he guiyin yu zizhu xuexi xingwei de guanxi yanjiu [Relationship between college students' autonomous learnig behavior and motivation, self-efficacy and attribution]. Foreign Language Learning: Theory and Practice, (2), 1-5.

[44] Lian, L.H., \& Yew, W.T. (2016). A Framework for Examining Assessment Literacy of Preservice Teachers. US-China Education Review A, 6(5), 294-300.

[45] Little, D. (2009). Language learner autonomy and the European language portfolio: Two L2 English examples. Language teaching, 42(2), 222-233.

[46] Malone, M.E. (2013). The Essentials of Assessment Literacy: Contrasts between Testers and Users. Language Testing 30(3), 329-344. DOI: 10.1177/0265532213480129.

[47] McBer, H. (2000). Research into Teacher Effectiveness: A model of teacher effectiveness, Department for Education and Employment. (2020, March 19), https://dera.ioe.ac.uk//4566/.

[48] Mertler, C. A. (2003, Oct.15). Pre-service versus in-service teachers' Assessment literacy: Does classroom experience make a Difference? Annual Meeting of the Mid-Western Educational Research Association, Columbus, $\mathrm{OH}$.

[49] Messick, S. (1989). Meaning and values in test validation: The science and ethics of assessment. Educational researcher, 18(2), 5-11.

[50] Mofrad, E. Z. (2016). Exploring the professional identity of the Iranian English teachers: The case of English institutes of Iranshahr. Theory and Practice in Language Studies, 6(4), 843-848.

[51] Moore, M., \& Hofman, J.E. (1988). Professional identity in institutions of higher learning in Israel. Higher Education, 17(1), 69-79.

[52] Morgan, B. (2004). Teacher identity as pedagogy: Towards a field-internal conceptualization in bilingual and second language education. In J. Brutt-Griffler \& M. Varghese (Eds.), Re-writing bilingualism and the bilingual educator's knowledge base (pp. 80-96). Clevedon, England: Multilingual Matters.

[53] Nunan, D. (2003). Nine steps to learner autonomy. Symposium, 2003, 193-204.

[54] Plake, B. S., Impara, J. C., \& Fager, J. J. (1993). Assessment competencies of teachers: A national survey. Educational Measurement: Issues and Practice, 12(4), 10-12.

[55] Popham, W. J. (2004). America's failing schools: How parents and teachers can cope with No Child Left Behind. New York: Routledge Falmer.

[56] Qi, A. (2011). On the relationships between learner autonomy and language proficiency: An investigation of Chinese English majors. Energy Procedia, (13), 9976-9982. 
[57] Rockoff, J.E. (2004). The impact of individual teachers on student achievement: Evidence from panel data. American Economic Review, 94(2), 247-252.

[58] Sakai, S., \& Takagi, A. (2009). Relationship between learner autonomy and English language proficiency of Japanese learners. The Journal of Asia TEFL, 6(3), 297-325.

[59] Scarino, A. (2013). Language assessment literacy as self-awareness: Understanding the role of interpretation in assessment and in teacher learning. Language Testing, 30(3), 309-327.

[60] Shim, K. N. (2009). An investigation into teachers' perceptions of classroom-based assessment of English as a foreign language in Korean primary education [Unpublished doctoral dissertation]. University of Exeter, Exeter.

[61] Stiggins, R. J. (1991). Assessment literacy. Phi Delta Kappan, 72(7), 534-539.

[62] Stiggins, R. J. (1999). Are you assessment literate? The High School Journal, 6(5), 20-23

[63] Suah, S. L. (2012). Analisis model literasid anamal an pentaksiran guru sekolah sertaka jiantentan gjurangan tarakeduanya \{Analysis of literacy model and assessment practices of school teachers and study of the culture gap /Unpublished Ph.D. dissertation]. School of Educational Studies, Universiti Sains Malaysia).

[64] Taylor, L. (2009). Developing assessment literacy. Annual Review of Applied Linguistics, 29, 21-36.

[65] Timoštšuk, I., \&Ugaste, A. (2010). Student teachers' professional identity. Teaching and teacher education, 26(8), 1563-1570.

[66] Tsagari, D., \& Vogt, K. (2017). Assessment Literacy of Foreign Language Teachers around Europe: Research, Challenges and Future Prospects, Papers in Language Testing and Assessment, 6(1), 41-63.

[67] Üstünlüoğlu, E. (2009). Autonomy in language learning: Do students take responsibility for their learning?. Journal of Theory \& Practice in Education, 5(2), 148-169.

[68] van Huizen, P., van Oers, B., \& Wubbels, T. (2005). A Vygotskian perspective on teacher education. Journal of curriculum studies, 37(3), 267-290.

[69] Varghese, M., Morgan, B., Johnston, B., \& Johnson, K. A. (2005). Theorizing language teacher identity: Three perspectives and beyond. Journal of language, Identity, and Education, 4(1), 21-44.

[70] Veisson, M., \& Kabaday, A. (2018). Exploring the Preschool Teachers' Views on Professionalism, Quality of Education and Sustainability: International Study in Estonia and Turkey. Journal of Teacher Education for Sustainability, 20(2), 5-18.

[71] Vickers, C.H., \& Ene, E. (2006). Grammatical accuracy and learner autonomy in advanced writing. ELT Journal, 60(2), 109116.

[72] Vogt, K., \& Tsagari, D. (2014). Assessment literacy of foreign language teachers: Findings of a European study. Language Assessment Quarterly, 11(4), 374-402.

[73] Volante, L., \& Fazio, X. (2007). Exploring Teacher Candidates' Assessment Literacy: Implications for Teacher Education Reform and Professional Development. Canadian Journal of Education, 30(3), 749-770.

[74] Wang, L., \& Du, X. (2016). Chinese language teachers' beliefs about their roles in the Danish context. System, 61, 1-11.

[75] Wu, X., \& Zhang, Q. (2009). Relationship between learning achievement and self-efficacy, learning strategies and learner autonomy. Foreign Language Education, 30(3), 43-62. https://doi.org/10.16362/j.cnki.cn61-1023/h.2009.03.019.

[76] Xu, Y., \& Brown, G. T. (2017). University English teacher assessment literacy: A survey-test report from China. Papers in Language Testing and Assessment, 6(1), 133-158.

[77] Yamtima, V., \& Wongwanich, S. (2014). A study of classroom assessment literacy of primary school teachers. Procedia Social and Behavioral Sciences 116, $2998-3004$.

[78] Yasmin, M., \& Sohail, A. (2017). Realizing learner autonomy in Pakistan: EFL teachers' beliefs about their practices. International Journal of English Linguistics, 8(2), 153-162.

[79] Yastıbaş, A. E., \& Takkaç, M. (2018). Understanding language assessment literacy: Developing language assessments. Journal of Language and Linguistic Studies, 14(1), 178-193.

[80] Zarei, A., \& Gahremani, K. (2010). On the relationship between learner autonomy and reading comprehension. TELL, 3 (10), 81-99.

[81] Zhalehgooyan, B., \& Alavi, S. M. (2014). Contribution of learner autonomy to listening comprehension problems of EFL learners. Frontiers of Language and Teaching, 5(1), 86-98.

[82] Zhang, L. X., \& Li, X. X. (2004). A comparative study on learner autonomy between Chinese students and west European students. Foreign Language World, 4, 15-23.

Hooshang Yazdani, Assistant Professor at Arak University, he has taught English as a foreign language for several years at Arak University. He was the supervisor of many MA thesis and P.h.D. dissertations. He has published several papers in scientific journals.

Parviz Ghasedi, P.h.D Candidate at Arak University, he has taught English as a foreign language at Arak University. He has participated in many national and international conferences as a lecture. He published many scientific articles in national and international journals. 